\title{
Phosphate Removal from Aqueous Solution by Aluminum (Hydr)oxide-coated Sand
}

\author{
Yong-Un Han, Seong-Jik Park, Chang-Gu Lee, Jeong-Ann Park, Nag-Choul Choi, Song-Bae Kim ${ }^{1}$ \\ Environmental Biocolloid Engineering Laboratory, Seoul National University, Seoul 151-921, Korea \\ ${ }^{1}$ Department of Rural Systems Engineering/Research Institute for Agriculture and Life Sciences, Seoul National University, Seoul 151-921, Korea
}

Received June 2009, accepted September 2009

\begin{abstract}
A powder form of aluminum (hydr)oxides is not suitable in wastewater treatment/filtration systems because of low hydraulic conductivity and large sludge production. In this study, aluminum (hydr)oxide-coated sand (AOCS) was used to remove phosphate from aqueous solution. The properties of AOCS were analyzed using a scanning electron microscopy (SEM) combined with an energy dispersive X-ray spectrometer (EDS) and an X-ray diffractometer (XRD). Kinetic batch, equilibrium batch, and closed-loop column experiments were performed to examine the adsorption of phosphate to AOCS. The XRD pattern indicated that the powder form of aluminum (hydr)oxides coated on AOCS was similar to a low crystalline boehmite. Kinetic batch experiments demonstrated that P adsorption to AOCS reached equilibrium after $24 \mathrm{~h}$ of reaction time. The kinetic sorption data were described well by the pseudo second-order kinetic sorption model, which determined the amount of $\mathrm{P}$ adsorbed at equilibrium $\left(q_{e}=0.118 \mathrm{mg} / \mathrm{g}\right)$ and the pseudo second-order velocity constant $(k=0.0036 \mathrm{~g} / \mathrm{mg} / \mathrm{h})$ at initial P concentration of $25 \mathrm{mg} / \mathrm{L}$. The equilibrium batch data were fitted well to the Freundlich isotherm model, which quantified the distribution coefficient $\left(K_{F}=0.083 \mathrm{~L} / \mathrm{g}\right)$, and the Freundlich constant $(1 / n=0.339)$. The closed-loop column experiments showed that the phosphate removal percent decreased from 89.1 to $41.9 \%$ with increasing initial $\mathrm{pH}$ from 4.82 to 9.53 . The adsorption capacity determined from the closed-loop experiment was $0.239 \mathrm{mg} / \mathrm{g}$ at initial $\mathrm{pH} 7.0$, which is about two times greater than that $\left(q_{e}=0.118 \mathrm{mg} / \mathrm{g}\right)$ from the kinetic batch experiment at the same condition.
\end{abstract}

Keywords: Aluminum-coated sand, Phosphate removal, Sorption, Batch experiment, Closed-loop column experiment

\section{Introduction}

Pollution of water bodies by phosphorus, an essential macronutrient, is a wide-spread environmental problem, causing eutrophication in lakes and seas and posing a great threat to aquatic environments. In environmental systems, the interaction between phosphate and aluminum (hydr)oxides has attracted considerable attention in two respects. The first concerns the reaction of phosphate with aluminum (hydr)oxide minerals in soils, which controls its availability to plants and leaching into water bodies. ${ }^{1-3)}$ The second is related to the removal of phosphate with aluminum (hydr)oxides. Through the application of positivelycharged aluminum (hydr)oxides as adsorbents, phosphate removal can be enhanced in tertiary wastewater treatment systems. ${ }^{4-6)}$

The adsorption of phosphate ions (monovalent: $\mathrm{H}_{2} \mathrm{PO}_{4}{ }^{-}$, divalent: $\mathrm{HPO}_{4}{ }^{2-}$ ) to aluminum (hydr)oxide surfaces can be described by ligand exchange mechanism. ${ }^{7,8)}$ In the adsorption process,

\footnotetext{
${ }^{+}$Corresponding author

E-mail: songbkim@snu.ac.kr

Tel: +82-2-880-4587, Fax: +82-2-873-2087
}

phosphate ions can replace hydroxyl ions $\left(\mathrm{OH}^{-}\right)$on the surfaces of aluminum (hydr)oxides, forming inner-sphere complexes including monodentate, bidentate, and binuclear complexes. ${ }^{4,9,10)}$ Also, this mechanism can be referred to as Lewis acid-base interaction in which phosphate ions (Lewis base) are adsorbed to the surface sites (Lewis acid) of aluminum (hydr)oxides. ${ }^{10,11)}$ Additionally, electrostatic (Coulombic) interaction can occur between positively-charged surfaces of aluminum (hydr)oxides and negatively-charged phosphate ions, forming outer-sphere complex. $^{2,4,10,12)}$

The removal of phosphate with aluminum (hydr)oxides has been investigated by several researchers. These studies have examined the sorption capacity of aluminum hydroxide $\left[\mathrm{Al}(\mathrm{OH})_{3}\right]$ for phosphate, ${ }^{13)}$ effect of $\mathrm{pH}$ on adsorption of phosphate to bauxite, which has a major mineral of boehmite $\left[\mathrm{\gamma}-\mathrm{AlO}(\mathrm{OH}){ }^{4}\right.$, enhancement of phosphate adsorption capacity through acid and heat treatments, ${ }^{14)}$ adsorption isotherms, rate, and selectivity of phosphate to aluminum oxide hydroxide, ${ }^{5)}$ influence of humic substances on phosphate adsorption on aluminum hydroxide, ${ }^{15)}$ competitive adsorption between phosphate and natural 
organic matter on aluminum hydroxide, ${ }^{16)}$ role of the surface acid-base properties of aluminum (hydr)oxides [pseudo- $\mathrm{\gamma}$ $\mathrm{AlO}(\mathrm{OH})$ and $\mathrm{a}-\mathrm{Al}_{2} \mathrm{O}_{3}$ ] in phosphate adsorption. ${ }^{17)}$

Because of low hydraulic conductivity and large sludge production, however, a powder form of aluminum (hydr)oxides is not suitable in wastewater treatment/filtration systems. Therefore, various granular forms of aluminum (hydr)oxide-coated media have been developed by several researchers including aluminum-loaded zeolite, ${ }^{18)}$ aluminum-coated silica sand and olivine, ${ }^{19)}$ granular aluminum oxide hydroxide, ${ }^{6}$ activated aluminum oxide, ${ }^{20)}$ and aluminum oxide-coated quartz sand. ${ }^{12)}$ The aluminum (hydr)oxide-coated media can be applied to adsorptive filtration systems for phosphate removal. Among these media, aluminum (hydr)oxide-coated sand (AOCS) is quite attractive for phosphate removal in the water filtration because sand is cheaper and more easily available than other filter media. ${ }^{21,22)}$

The objective of this study was to investigate the removal of phosphate from aqueous solution using aluminum (hydr)oxidecoated sand (AOCS). The properties of AOCS were analyzed using a scanning electron microscopy (SEM) combined with an energy dispersive X-ray spectrometer (EDS) and an X-ray diffractometer (XRD). Kinetic batch, equilibrium batch, and closedloop column experiments were performed to examine the adsorption of phosphate to AOCS.

\section{Materials and Methods}

\subsection{Aluminum (Hydr)oxide-coated Sand}

Quartz sand (Jumunjin Silica, Korea) was used to prepare AOCS. Mechanical sieving was conducted with US Standard Sieves (Fisher Scientific) Nos. 35 and 10. Sand fractions with a grain size of $0.52 .0 \mathrm{~mm}$ and a mean diameter of $1.0 \mathrm{~mm}$ were used in the experiments. Before use, sand was washed twice using deionized water to remove impurities on the surface, and wet sand was autoclaved at $121^{\circ} \mathrm{C}$ and 17.6 psi for $20 \mathrm{~min}$, cooled to room temperature, and oven-dried at $105^{\circ} \mathrm{C}$ for 12 days. For the preparation of AOCS, $\mathrm{AlCl}_{3} \cdot 6 \mathrm{H}_{2} \mathrm{O}(4.9 \mathrm{~g})$ was dissolved in deionized water $(100 \mathrm{~mL})$, and the solution $\mathrm{pH}$ was adjusted with $6 \mathrm{~N} \mathrm{NaOH}$ to $\mathrm{pH}$ 7.0. The quartz sand $(200 \mathrm{~g})$ was added to the $\mathrm{AlCl}_{3} \cdot 6 \mathrm{H}_{2} \mathrm{O}$ solution and then mixed in a rotary evaporator $\left(90^{\circ} \mathrm{C}, 80 \mathrm{rpm}, 20 \mathrm{~min}\right)$ to remove water in the suspension by heating (Hahnvapor, Hahnshin Scientific Co., Korea). The coated sand was dried at $150^{\circ} \mathrm{C}$ for $6 \mathrm{~h}$, washed with deionized water, and then dried again using the same conditions. The powder form of aluminum (hydr)oxides made in our laboratory was characterized by a powder X-ray diffractometry (XRD, D5005, Bruker, Germany) with a $\mathrm{Cu} \mathrm{K} \alpha$ radiation. The scanning electron microscopy (SEM) and energy dispersive X-ray spectrometer (EDS) analysis were performed using a scanning electron microscope (JSM 5410LV, JEOL, Japan) to examine the presence of $\mathrm{Al}$ and $\mathrm{P}$ on the coated sand.

\subsection{Kinetic and Equilibrium Batch Experiments}

Phosphate adsorption to AOCS was determined by using kinetic and equilibrium batch experiments. Kinetic batch tests were performed at the initial phosphate concentrations of 25 and $100 \mathrm{mg} / \mathrm{L}$ with initial $\mathrm{pH}$ of 7.0 and $\mathrm{NaNO}_{3}$ of $0.02 \mathrm{M}$. Five grams of AOCS were added to $30 \mathrm{~mL}$ phosphate $\left(\mathrm{KH}_{2} \mathrm{PO}_{4}\right)$ solution in $50 \mathrm{~mL}$ polypropylene conical tubes. The concentration of $\mathrm{NaNO}_{3}$ was fixed at $0.02 \mathrm{M}$ as background electrolyte. The solution $\mathrm{pH}$ was adjusted to $\mathrm{pH} 7$ with $0.1 \mathrm{M} \mathrm{NaOH}$ and/or $0.1 \mathrm{M} \mathrm{HCl}$. The tubes were shaken at $30 \pm 0.5^{\circ} \mathrm{C}$ and $140 \mathrm{rpm}$ using shaking incubator (SHAK116, Daihan Scientific, Korea). The sample was taken at $1,3,6,9,12,24$, and $48 \mathrm{~h}$ after reaction and filtered through $0.45 \mu \mathrm{m}$ membrane filter. Phosphate was analyzed by the ascorbic acid method. ${ }^{23)}$ Phosphate concentration was measured at a wavelength of $880 \mathrm{~nm}$ using a UV vis spectrophotometer (Helios, Thermo, USA). Equilibrium batch tests were conducted with initial phosphate concentrations ranging from 10 to $200 \mathrm{mg} / \mathrm{L}$. The same procedure used for the kinetic test was followed in the experiments with the sampling time of $24 \mathrm{~h}$ after reaction. All the experiments were performed in triplicate.

\subsection{Closed-Loop Column Experiments}

Closed-loop column experiments (Figure 1) were performed using a Plexiglas column (diameter: $2.5 \mathrm{~cm}$; height: $10 \mathrm{~cm}$ ) packed with AOCS (mass of medium: $75.58 \pm 1.24 \mathrm{~g}$ ). A column was packed for each experiment by the tap-fill method to attain a bulk density of $1.565 \pm 0.008 \mathrm{~g} / \mathrm{cm}^{3}$ and a porosity of $0.410 \pm$ 0.003 . A phosphate solution $(25 \mathrm{mg} / \mathrm{L}, 1000 \mathrm{~mL})$ was prepared with $0.02 \mathrm{M} \mathrm{NaNO}_{3}$ as background electrolyte. The solution $\mathrm{pH}$ was adjusted to a desired value with $0.1 \mathrm{M} \mathrm{NaOH}$ and/or $0.1 \mathrm{M}$ $\mathrm{HCl}$. The column was connected to a FMI pump (QG400, Fasco, USA) operating at a rate of $5.0 \mathrm{~mL} / \mathrm{min}$. The experiment was performed by circulating the phosphate solution for $24 \mathrm{~h}$. After completing the experiment, samples were collected and analyzed for phosphate concentration and $\mathrm{pH}$. Phosphate concentration was determined as mentioned above. The $\mathrm{pH}$ was measured with a $\mathrm{pH}$ probe $(9107 \mathrm{BN}$, Orion, USA).

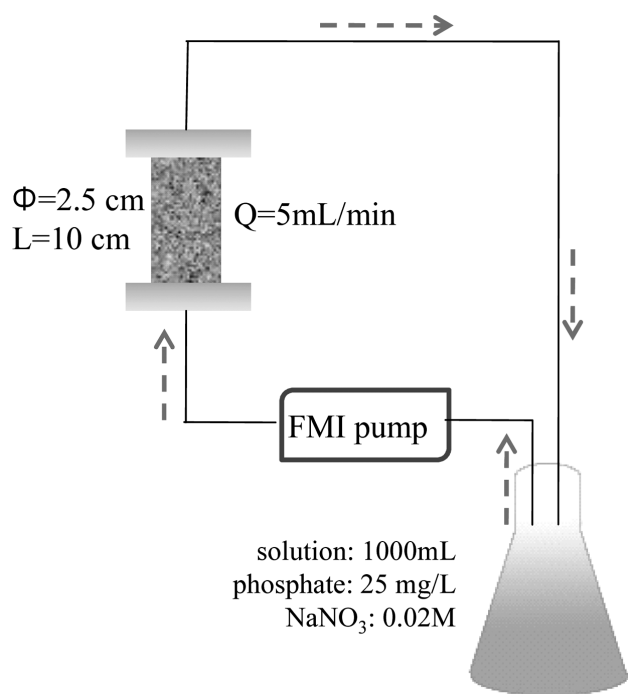

Fig. 1. Schematic diagram of closed-loop column experiment. 


\subsection{Data Analysis}

The adsorption kinetic data were analyzed by the following the Lagergren first-order and pseudo second-order models: $:^{24,25)}$

$$
\begin{gathered}
q_{t}=q_{e}\left[1-\exp \left(-K_{L} t\right)\right] \\
\frac{1}{q_{e}-q_{t}}=\frac{1}{q_{e}}+k t
\end{gathered}
$$

where $q_{t}$ is the amount of phosphate adsorbed at time $\mathrm{t}(\mathrm{mg} / \mathrm{g}), q_{e}$ is the amount of phosphate adsorbed at equilibrium $(\mathrm{mg} / \mathrm{g}), K_{L}$ is the Lagergren rate constant $(1 / \mathrm{h})$, and $k$ is the pseudo secondorder velocity constant $(\mathrm{g} / \mathrm{mg} / \mathrm{h})$. The adsorption isotherm data were analyzed by the following Langmuir and Freundlich isotherm models:

$$
\begin{gathered}
S=\frac{Q_{m} K_{L} C}{1+K_{L} C} \\
S=K_{F} C^{1 / n}
\end{gathered}
$$

where $S$ is the mass of solute adsorbed per unit mass of adsorbent $(\mathrm{mg} / \mathrm{g}), C$ is the concentration of solute in the aqueous solution at equilibrium $(\mathrm{mg} / \mathrm{L}), K_{L}$ is the Langmuir adsorption constant related to the binding energy $(\mathrm{L} / \mathrm{mg}), Q_{m}$ is the maximum mass of solute adsorbed per unit mass of adsorbent (adsorption capacity) $(\mathrm{mg} / \mathrm{g}), K_{F}$ is the distribution coefficient $(\mathrm{L} / \mathrm{g})$, and $1 / n$ is the Freundlich constant. Values of $K_{L}, Q_{m}, K_{F}$, and $1 / n$ can be determined from the linear forms of the Langmuir and Freundlich models.

\section{Results and Discussion}

\subsection{Characteristics of Aluminum (Hydr)oxide-coated Sand}

The XRD pattern for the powder form of aluminum (hydr) oxide is shown in Figure 2, which is similar to that of a low crystalline boehmite. ${ }^{5,11)}$ The surface characteristics and chemical composition of AOCS was presented in Figure 3. The photo and SEM images showed the color, size, and shape of AOCS granules (Figure 3(a) and 3(b)). The SEM images of AOCS surfaces before and after phosphate adsorption were given in Figure 3(c) and 3(e), respectively, indicating that aluminum (hydr)oxide particles partly covered the surfaces of quartz sand. In addition, the EDS pattern after phosphate adsorption (Figure 3(f)) was similar to that before adsorption (Figure 3(d)), except for the phosphate peak. The major constituents of AOCS were Si and Al.

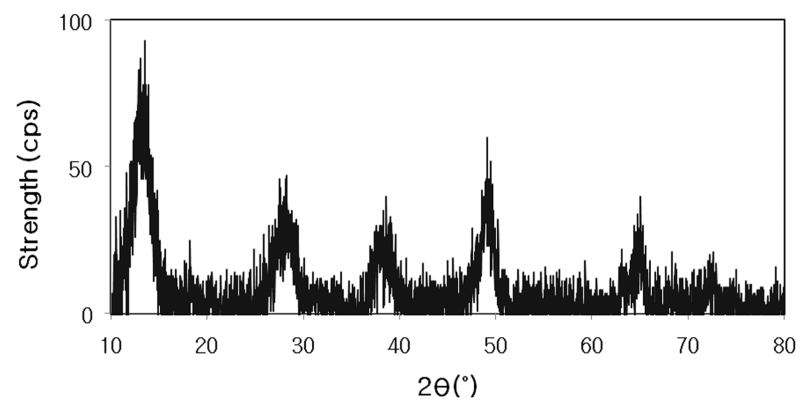

Fig. 2. X-ray diffraction pattern for powder form of aluminum (hydr) oxide.

\subsection{Phosphate Adsorption to Aluminum (Hydr)oxide-coated Sand}
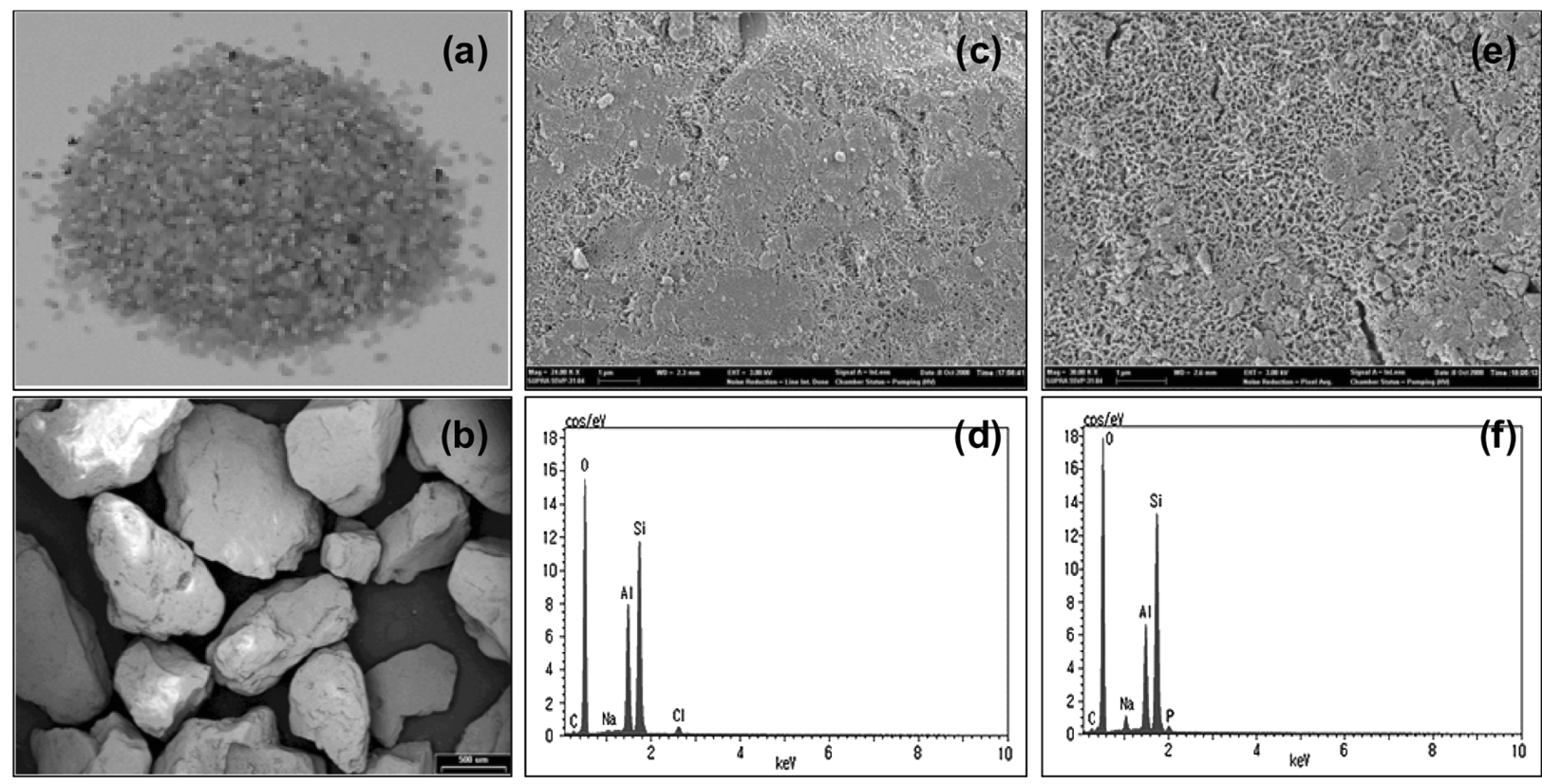

Fig. 3. Aluminum (hydr)oxide-coated sand: (a) photo image, (b) SEM image (bar $=50 \mu \mathrm{m})$, (c) SEM image before phosphate adsorption (bar $=1 \mu \mathrm{m})$, (d) EDS before phosphate adsorption, (e) SEM image after phosphate adsorption (bar = $1 \mu \mathrm{m})$, (f) EDS after phosphate adsorption. 
The adsorption kinetics of phosphate in AOCS is shown in Figure 4 . The adsorption reached equilibrium after $24 \mathrm{~h}$ of reaction time. Model parameters for Lagergren first-order and pseudo second-order models obtained from the kinetic experiments are presented in Table 1 . In the first-order model, the value of $q_{e}$ at $25 \mathrm{mg} / \mathrm{L}$ of phosphate was $0.112 \mathrm{mg} / \mathrm{g}$. At $100 \mathrm{mg} / \mathrm{L}$, it was $0.205 \mathrm{mg} / \mathrm{g}$, which is about two times greater than that $25 \mathrm{mg} / \mathrm{L}$. The value of $K_{L}$ at $25 \mathrm{mg} / \mathrm{L}$ was $0.1531 / \mathrm{h}$ while it was $0.177 \mathrm{1} / \mathrm{h}$ at $100 \mathrm{mg} / \mathrm{L}$, indicating that the reaction rate at $100 \mathrm{mg} / \mathrm{L}$ was faster than that at $25 \mathrm{mg} / \mathrm{L}$. The values of $q_{e}$ from the pseudo second-order model were similar to those from the first-order model. At $25 \mathrm{mg} / \mathrm{L}$, the value of $q_{e}$ was $0.118 \mathrm{mg} / \mathrm{g}$ while it was $0.208 \mathrm{mg} / \mathrm{g}$ at $100 \mathrm{mg} / \mathrm{L}$. The values of $k$ at $25 \mathrm{mg} / \mathrm{L}$ and $100 \mathrm{mg} / \mathrm{L}$ were $0.0036 \mathrm{~g} / \mathrm{mg} / \mathrm{h}$ and $0.0033 \mathrm{~g} / \mathrm{mg} / \mathrm{h}$, indicating that the velocity constants of the second-order model were similar at both phosphate concentrations. The correlation coefficients $\left(R^{2}\right)$ in Table 1 indicated that the pseudo second-order model was more proper at describing the kinetic data than the first-order model. The pseudo second-order model describes heterogeneous systems where the phosphate sorption is ascribed to the chemical sorption mechanism.

The equilibrium adsorption isotherms of phosphate on AOCS are presented in Figure 5. In the Freundlich model, the distribution coefficient $\left(K_{F}\right)$ was $0.083 \mathrm{~L} / \mathrm{g}$ while the Freundlich constant $(1 / n)$ was 0.339 . In the Langmuir model, the adsorption constant $\left(K_{L}\right)$ was $0.3053 \mathrm{~L} / \mathrm{mg}$ while the adsorption capacity $\left(Q_{m}\right)$ was $0.292 \mathrm{mg} / \mathrm{g}$. The correlation coefficient $\left(R^{2}\right)$ of the Freundlich model was $(=0.97)$ greater than that of the Langmuir model $(=0.67)$, indicating that the Freundlich isotherm was appropriate at describing the experimental result. The Freundlich

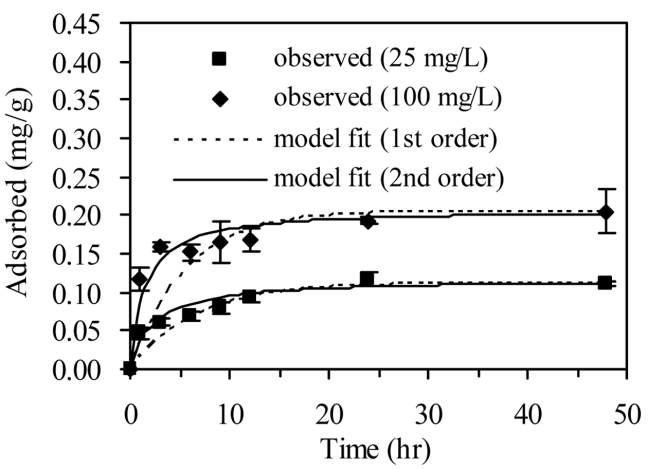

Fig. 4. Kinetic batch data with model fittings of the Lagergren firstorder and pseudo second-order kinetic models.

isotherm model is used to describe the multilayer adsorption at adsorption sites.

The phosphate removal in closed-loop column experiments is summarized in Table 2 . The adsorption capacity of AOCS determined from the closed-loop experiments ranged from 0.296 to $0.137 \mathrm{mg} / \mathrm{g}$, depending on the solution $\mathrm{pH}$. At initial $\mathrm{pH} 7.0$, the adsorption capacity was $0.239 \mathrm{mg} / \mathrm{g}(0.232 \mathrm{mg} / \mathrm{g}$ at $\mathrm{pH} 6.98$,

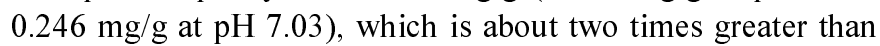
that $(\mathrm{qe}=0.118 \mathrm{mg} / \mathrm{g}$ ) obtained from the kinetic batch experi-

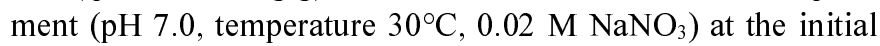
phosphate concentration of $25 \mathrm{mg} / \mathrm{L}$. This discrepancy can be attributed to the differences in experimental type, medium-tosolution ratio, and among others. Note that the medium-to-solution ratio in kinetic batch experiments was 1:6 (medium of $5 \mathrm{~g}$ : solution of $30 \mathrm{~mL}$ ) while it was $3.8: 1$ (bulk density of $1.565 \mathrm{~g} / \mathrm{cm}^{3}$ : porosity of 0.410 ) in closed-loop column experiments.

Table 1. Model parameters for the Lagergren first-order model and pseudo second-order model obtained from the kinetic experiments

\begin{tabular}{ccccccc}
\hline \multirow{2}{*}{$\begin{array}{c}\text { Initial } \mathrm{P} \\
\text { concentration } \\
(\mathrm{mg} / \mathrm{L})\end{array}$} & \multicolumn{3}{c}{ Lagergren first-order model } & \multicolumn{3}{c}{ pseudo second-order model } \\
\cline { 2 - 6 } & $\begin{array}{c}\mathrm{q}_{\mathrm{y}} \\
(\mathrm{mg} / \mathrm{g})\end{array}$ & $\begin{array}{c}\mathrm{K}_{\mathrm{L}} \\
(1 / \mathrm{h})\end{array}$ & $\mathrm{R}^{2}$ & $\begin{array}{c}\mathrm{q}_{\mathrm{e}} \\
(\mathrm{mg} / \mathrm{g})\end{array}$ & $\begin{array}{c}\mathrm{k} \\
(\mathrm{g} / \mathrm{mg} / \mathrm{h})\end{array}$ \\
\hline 25 & 0.112 & 0.153 & 0.735 & 0.118 & 0.0036 \\
100 & 0.205 & 0.177 & 0.929 & 0.208 & 0.0033 & 0.996 \\
\hline
\end{tabular}

Table 2. Experimental conditions and results for phosphate removal with aluminum (hydr)oxide-coated sand in closed-loop column experiments

\begin{tabular}{|c|c|c|c|c|c|c|c|}
\hline Ex & $\begin{array}{l}\text { Initial P } \\
\left(\mathrm{mg} \mathrm{L}^{-1}\right)\end{array}$ & $\begin{array}{c}\text { Initial } \\
\mathrm{pH}\end{array}$ & $\begin{array}{l}\text { Final P } \\
\left(\mathrm{mg} \mathrm{L}^{-1}\right)\end{array}$ & $\begin{array}{c}\text { Final } \\
\mathrm{pH}\end{array}$ & $\triangle \mathrm{pH}^{*}$ & Removal (\%) & $\begin{array}{l}\text { Mass removal } \\
(\mathrm{mg} / \mathrm{g})^{\#}\end{array}$ \\
\hline 1 & 25.0 & 4.82 & 3.1 & 5.91 & 1.09 & 87.7 & 0.296 \\
\hline 2 & 25.0 & 4.98 & 2.7 & 6.32 & 1.34 & 89.1 & 0.293 \\
\hline 3 & 25.0 & 5.75 & 3.5 & 6.80 & 1.05 & 85.9 & 0.281 \\
\hline 4 & 25.0 & 6.50 & 50 & 6.70 & 0.20 & 80.0 & 0.266 \\
\hline 5 & 25.0 & 6.98 & 7.3 & 7.22 & 0.24 & 70.9 & 0.232 \\
\hline 7 & 25.0 & 7.22 & 8.5 & 7.09 & -0.13 & 66.1 & 0.225 \\
\hline 8 & 25.0 & 8.00 & 12.4 & 7.65 & -0.35 & 50.6 & 0.167 \\
\hline 9 & 25.0 & 8.32 & 10.6 & 7.98 & -0.34 & 57.5 & 0.195 \\
\hline 10 & 25.0 & 9.02 & 9.9 & 7.75 & -1.27 & 60.3 & 0.197 \\
\hline 11 & 25.0 & 9.17 & 14.5 & 7.92 & -1.25 & 41.9 & 0.137 \\
\hline
\end{tabular}

${ }^{*} \triangle \mathrm{pH}=$ Final $\mathrm{pH}$ Initial $\mathrm{pH}$

" Mass of phosphate removed per unit mass of coated sand 


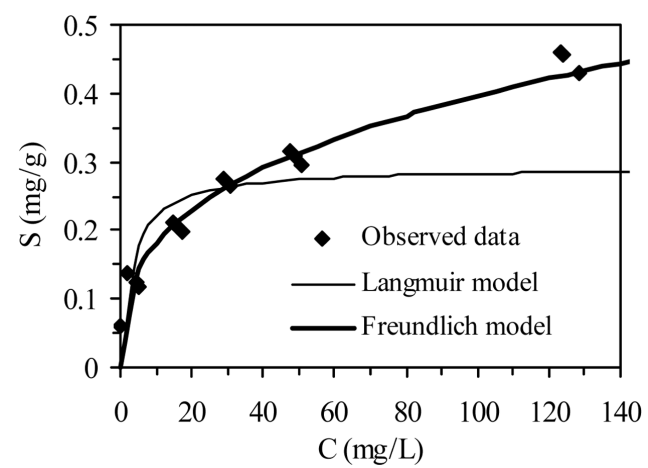

Fig. 5. Equilibrium batch data with model fittings of the Freundlich and Langmuir isotherms.

\subsection{Phosphate Removal and Solution $\mathrm{pH}$}

The phosphate removal percent in AOCS decreased with increasing solution $\mathrm{pH}$ (Figure 6). This decreasing tendency can be attributed to the charge modification of adsorption sites and the competition between phosphate ions and hydroxyl ions. As solution $\mathrm{pH}$ increases, the surface sites on aluminum (hydr)oxides become less positively-charged and further change to the negatively-charged above $\mathrm{pH}_{\mathrm{pzc}}$ (point of zero charge, 9.7). ${ }^{26)}$ Furthermore, the concentration of hydroxyl ions increases with increasing $\mathrm{pH}$, and thus the competition between phosphate ions and hydroxyl ions to the adsorption sites of aluminum (hydr) oxides is enhanced. ${ }^{18)}$ Our result is consistent with the result of Tanada et al. ${ }^{5)}$ who have shown that the amount of phosphate adsorbed to aluminum oxide hydroxide decreased with increasing initial $\mathrm{pH}$ from 4.0 to 8.5. Another batch experiment ${ }^{2}$ has shown that the adsorption density of orthophosphate $(6 \mathrm{mM})$ to $\mathrm{\gamma}-\mathrm{Al}_{2} \mathrm{O}_{3}$ decreased with increasing $\mathrm{pH}$ from 4.0 to 10.0 . Other experiment ${ }^{3}$ ) has also demonstrated that phosphate content in solution after reaction with boehmite and $\mathrm{\gamma}-\mathrm{Al}_{2} \mathrm{O}_{3}$ decreased with increasing $\mathrm{pH}$ from 3.0 to 11.0 . The similar results were also found from other experiments. ${ }^{4,18)}$

The $\mathrm{pH}$ differences (final $\mathrm{pHs}$ - initial $\mathrm{pHs}$ ) determined from the closed-loop column experiments are presented in Figure 7. In the experiments 1-6 (Table 2), the $\mathrm{pH}$ differences between the initial and the final were positive and tended to decrease with increasing $\mathrm{pH}$. Meanwhile, the $\mathrm{pH}$ differences between the initial and the final were negative and tended to decrease with decreasing $\mathrm{pH}$ in the experiments $7-2$ (Table 2). It is well known

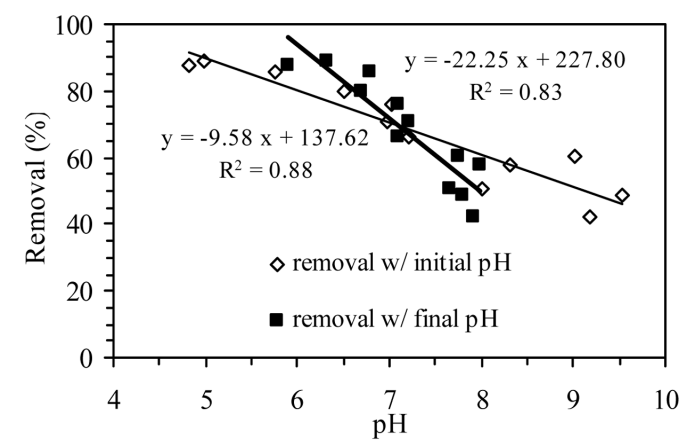

Fig. 6. Percent removal of phosphate from closed-loop column experiment under different solution $\mathrm{pH}$ conditions. that ligand exchange is the main mechanism in the adsorption of phosphate to aluminum hydr(oxide) surfaces. Hydroxyl ions are released into the solution during the experiment, resulting in the increase of solution $\mathrm{pH}$. In our experiments with a sufficient reaction time, phosphate ions can play a buffering role in the solution through protonation/deprotonation between $\mathrm{H}_{2} \mathrm{PO}_{4}{ }^{-}$and $\mathrm{HPO}_{4}{ }^{2-}$, tending to neutralize the solution $\mathrm{pH}$. Between $\mathrm{pH} 4.0$ and 7.0, the solution pHs increased due to the buffering role of phosphate ions in addition to the release of hydroxyl ions, while they decreased between pH 7.0 and 10.0 due to the role of phosphate ions against the release of hydroxyl ions. Our result is not consistent with the report of Tanada et al. ${ }^{5)}$ who have shown that the final solution pHs were larger than the initial in all batch experiments for the phosphate adsorption to aluminum oxide hydroxide. Another experiment ${ }^{4)}$ also demonstrated that all the solution $\mathrm{pHs}$ increased after the phosphate adsorption reaction in bauxite. This discrepancy may be ascribed to the different experimental conditions between their studies and ours including reaction time and solution volume, among others. In our experiments, reaction time was $24 \mathrm{~h}$ with solution volume of $1000 \mathrm{~mL}$ while it was $2 \mathrm{~h}$ with $100 \mathrm{~mL}$ in their batch experiments. ${ }^{4)}$ Note that no information was provided from Tanada et al. ${ }^{5)}$ regarding their reaction time and solution volume.

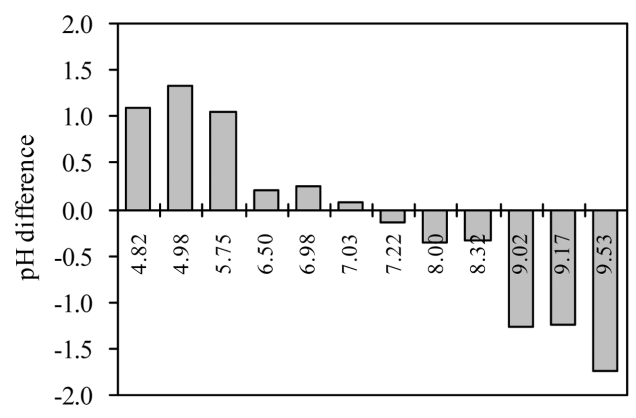

Fig. 7. $\mathrm{pH}$ difference (final $\mathrm{pH}$-initial $\mathrm{pH}$ ) determined from closed-loop column experiment (numbers in $\mathrm{x}$-axis $=$ initial $\mathrm{pH}$ ).

\section{Conclusions}

The adsorption of phosphate to AOCS was investigated in this study using kinetic batch, equilibrium batch, and closed-loop column experiments. The XRD pattern indicated that the powder form of aluminum (hydr)oxide coated on AOCS was similar to a low crystalline boehmite. Kinetic batch experiments showed that $\mathrm{P}$ adsorption to AOCS reached equilibrium after $24 \mathrm{~h}$ of reaction time. The kinetic sorption data were described well by the pseudo second-order kinetic sorption model while the equilibrium batch data were fitted well to the Freundlich isotherm model. The closed-loop column experiments showed that the phosphate removal percent decreased with increasing solution $\mathrm{pH}$. This tendency can be attributed to the charge modification of adsorption sites and the competition between phosphate ions and hydroxyl ions. The adsorption capacity determined from the closed-loop experiment was about two times greater than that from the kinetic batch experiment at the same condition. This discrepancy can be ascribed to the differences in experimental type and medium-to-solution ratio. 


\section{References}

1. Lookman, R., Grobet, P., Merckx, R., and Vlassak, K., "Phosphate sorption by synthetic amorphous aluminum hydroxides: $\mathrm{A}{ }^{27} \mathrm{Al}$ and ${ }^{31} \mathrm{P}$ solid-state MAS NMR spectroscopy study," European J. Soil Sci., 45, 37-44 (1994).

2. Johnson, B. B., Ivanov, A. V., Antzutkin, O. N., and Forsling, W., ${ }^{، 13} \mathrm{P}$ nuclear magnetic resonance study of the adsorption of phosphate and phenyl phosphates on $\mathrm{\gamma}-\mathrm{Al}_{2} \mathrm{O}_{3}$," Langmuir, 18, 1104-1111 (2002).

3. Kim, Y. and Kirkpatrick, R. J., "An investigation of phosphate adsorbed on aluminum oxyhydroxide and oxide phases by nuclear magnetic resonance," European J. Soil Sci., 55, 243-251 (2004).

4. Altundoğan, H. S. and Tümen, F., "Removal of phosphate from aqueous solutions by using bauxite. I : Effect of $\mathrm{pH}$ on the adsorption of various phosphates," J. Chem. Technol. Biotechnol., 77, 77-85 (2001).

5. Tanada, S., Kabayama, M., Kawasaki, N., Sakiyama, T., Nakamura, T., Araki, M., and Tamura, T., "Removal of phosphate by aluminum oxide hydroxide," J. Colloid Interf. Sci., 257, 135-140 (2003).

6. Kabayama, M., Sakiyama, T., Kawasaki, N., Nakamura, T., Araki, M., and Tanada, S., "Characteristics of phosphate ion adsorption-desorption onto aluminum oxide hydroxide for preventing eutrophication," J. Chem. Eng. Japan, 36, 499-505 (2003).

7. Rajan, S. S. S., "Adsorption of divalent phosphate on hydrous aluminum oxide," Nature, 253, 434-436 (1975).

8. Shin, E. W., Han, J. S., Jang, M., Min, S. H., Park, J. K., and Rowell, R. M., "Phosphate adsorption on aluminum-impregnated mesoporous silicates: Surface structure and behavior of adsorbents," Environ. Sci. Technol., 38, $912-917$ (2004).

9. Guan, X. H., Liu, Q., Chen, G. H., and Shang, C., "Surface complexation of condensed phosphate to aluminum hydroxide: An ATR-FTIR spectroscopic investigation," J. Colloid Interf. Sci., 289, 319-327 (2005).

10. Blaney, L. M., Cinar, S., and Sengupta, A. K., "Hybrid anion exchanger for trace phosphate removal from water and wastewater," Water Res., 41, 1603-1613 (2007).

11. Boujelben, N., Bouzid, J., Elouear, Z., Feki, M., Jamoussi, F., and Montiel, A., "Phosphorus removal from aqueous solution using iron coated natural and engineered sorbents," J. Hazard. Mater., 151, 103-110 (2008).

12. Arias, M., Da Silva-Carballal, J., Carcía-Río, L., Mejuto, J., and Núñez, A., "Retention of phosphorus by iron and aluminum-oxides-coated quartz particles," J. Colloid Interf.
Sci., 295, 65-70 (2006).

13. Galarneau, E. and Gehr, R., "Phosphorus removal from wastewaters: Experimental and theoretical support for alternative mechanisms," Water Res., 31, 328-338 (1997).

14. Altundoğan, H. S. and Tümen, F., "Removal of phosphates from aqueous solutions by using bauxite II: The activation study," J. Chem. Technol. Biotechnol., 78, 824-833 (2003).

15. Borggaard, O. K., Raben-Lange, B., Gimsing, A. L., and Strobel, B. W., "Influence of humic substances on phosphate adsorption by aluminum and iron oxides," Geoderma, 127, 270-279 (2005).

16. Guan, X. H., Shang, C. S., and Chen, G. H., "Competitive adsorption of organic matter with phosphate on aluminum hydroxide," J. Colloid Interf. Sci., 296, 51-58 (2006).

17. Xiaofang, Y., Zhonxi, S., Dongsheng, W., and Forsling, W., "Surface acid-base properties and hydration/dehydration mechanisms of aluminum (hydr)oxides," J. Colloid Interf. Sci., 308, 395-404 (2007).

18. Xu, Y. H., Ohki, A., and Maeda, S., "Removal of arsenate, phosphate, and fluoride ions by aluminum-loaded shirasuzeolite," Toxicol. Environ. Chem., 76, 111-124 (2000).

19. Ayoub, G. M., Koopman, B., and Pandya, N., "Iron and aluminum hydroxy(oxide) coated filter media for low-concentration phosphorus removal," Water Environ. Res., 73, 478-485 (2001).

20. Genz, A., Kornmüller, A., and Jekel, M., "Advanced phosphorus removal from membrane filtrates by adsorption on activated aluminum oxide and granulated ferric hydroxide," Water Res., 38, 3523-3530 (2004).

21. Edwards, M. and Benjamin, M., "Adsorptive filtration using coated sand: A new approach for treatment of metal-bearing wastes," J. Water Pollut. Control Fed., 61, 1523-1533 (1989).

22. Vaishya, R. C. and Gupta, S. K., "Coated sand filtration: An emerging technology for water treatment," J. Water Supply, 52, 299-306 (2003).

23. APHA(American Public Health Association), Standard Methods for the Examination of Water and Wastewater, Washington, DC. (1995).

24. Mathialagan, T. and Viraraghavan, T., "Adsorption of cadmium from aqueous solutions by vermiculite," Sep. Sci. Technol., 38, 57-76 (2003).

25. Ho, Y. S. and Mckay, G., "Pseudo-second order model for sorption processes," Process Biochem., 34, 451-465 (1999).

26. Fein, J. B., Boily, J. F., Güçlü, K., and Kaulbach, E., "Experimental study of humic acid adsorption onto bacteria and Al-oxide mineral surfaces," Chem. Geol., 162, 33-45 (1999). 